\title{
Emilio salgari, a writer for armchair travelers
}

\begin{abstract}
Emilio Salgari constructed the exotic fiction for the national-popular public of Italy. His influence on the creation of the 'Italian' Indian has been deeply felt by both Italian cartoons and movies.
\end{abstract}

Keywords: salgari, native americans, exotic fiction
Volume I Issue 2 - 2017

Flavia Busatta

Department of anthropology, Italy

Correspondence: Flavia Busatta, Padova, Italy, Tel +39 049663072, Email flavia@hakomagazine.net

Received: April 17, 2017| Published: April 25, 2017

\section{Introduction}

Emilio Salgari was born in Verona, northeastern Italy in 1862 and attended the Nautical School in Venice until 1881 when he interrupted his studies and found a job on a freighter sailing along the coasts of the Adriatic and Mediterranean Seas. Though he thereafter spoke of fabulous journeys in faraway countries this was his only real "exotic" experience even though he traveled the world's oceans and seas in his writings,

Salgari left his job on the freighter for unknown reasons and began his career as a writer publishing the short story The Savages of Papuasia in 1883. After that his life became an overwrought sequence of days full of arguments with his publishers, debts, removals, illnesses and accidents. In 1892 he married and moved to Turin the economic capital of king Umberto's Italy, following a route many Venetians had covered before to create the FIAT's wealth under the shadow of the Basilica of Superga. Later, because of a contract with a publisher, he moved to Sanpierdarena (Genoa), but his gloomy disposition, economical problems and his wife's incipient insanity induced him to go back to Turin after only two years. Between 1883, the year of his literary beginning and his suicide in 1911, Salgari published more than seventy books, novels, short stories and "adventures", an average of two books a year, always under pressure from the publishers' noose contracts. His tragic economic troubles together with the fact that many novels were published in installments in magazines and papers, also explain his peculiar style, the frequent use of onomatopoeic and exclamatory words in the dialogues and the lingering on repetitive, verbose descriptions: the poor man was paid a certain amount per line!

Salgari's works develop some fundamental cycles dictated by the publishing market among them there are the Cycle of the Malayan Pirates that of the Privateers and Buccaneers and of the Far West, the African Adventures and the Adventures in the East. ${ }^{1}$ This writer ${ }^{1}$ The Cycle of the Malayan Pirates comprises The Mysteries of the Black Jungle, Mompracem Tigers, TheTwo Tigers, The Sea King, Conquering an Empire, Sandokan to Arms!, Mompracem Reconquered, The Brahmin of Assam, The Fall of an Empire, The Pirates of Malaya, Yanez's Revenge; the Cycle of the Far West comprises the trilogy On the Frontiers of the Far West, The Woman Scalper, The Burning Woods (Salgari's rendering of the Brulé) and other novels such as The Queen of the Golden Field, The Prairie King, Adventures among the Redskins, The Miners of Alaska, Red Stories, The Scalper; the Cycle of the Privateers comprises the trilogy The Black Corsair, The Queen of the Caribbean, Jolanda, the Black Corsair's Daughter, and The Red Corsair's Son, The Last Buccaneers, The Corsairs of the Bermudas, The Cruise of the "Thundering", Stone Head's Extraordinary Adventures; the African adventures comprise, among the others, The Favorite of the Madhi, The Sahara Marauders, The Bandits of the Riff, Ivory Coast, On the Atlantis; of popular serial novels, cut off from the Italian intellectual debate and Central European ferment of his time but sharing the feelings of the petit bourgeois flag-wavers of King Umberto's ${ }^{2}$ and Giolitti's ${ }^{3}$ Italy, shows his literary taste by means of a prose that owes a lot to Giuseppe Verdi and other artists of melodrama. In fact characters and passions are foreshortened and elemental roughly outlined with little psychological and thematic preoccupation. We find the same incapacity to read in depth minds and souls the same type of complicated as well as improbable and naive plot of the librettos where the "popular" is such only for lack of analysis and complexity. But Salgari's work is made of novels and short stories not librettos and lacks the music that can express with the right orchestra "the Italian soul", robustly vital and quite virgin, though indeterminate and inconsistent.

In Salgari's work, a typical example of the Italian popular historical novel the reader can find contemporary events such as the Madhi Revolt or the Wounded Knee Massacre. Fictitious characters are inserted into a historical context which allows the writer learned digressions for example on the conquest of the West or the buccaneers

among the adventures in the East we remember: Buddha's Scimitar, The King of the Mountain, The Flower of the Pearls, The Philippines'Slaughters. There are also some novels not belonging to any cycle such as The Woman Captain of the "Yucatan", The Lion of Damascus, Captain Storm, Adventures on the Prairies, the Jungle and the Sea and many short stories.

${ }^{2}$ During Umberto I. reign (1878-1900) the Left obtained the power with the Prime Minister De Pretis (1876-1887), who introduced the so called Transformism, that is the dissolution of ideologically and politically defined alignments in Parliament and the formation of government majorities made of particular interests. This policy disintegrated the political groups which had fought in the Risorgimento and promoted laws such as compulsory elementary education, abolition of the tax on flour, widened franchise and saw the birth of the Triple Alliance with Prussia and the ex enemy, the Austro-Hungarian Empire. This alliance was to support the colonial expansion of the Reign of Italy. Among the most important politicians of the period is Francesco Crispi, ex Garibaldine, then a monarchic conservative, who was Prime Minister from 1887 to 1896 . As an admirer of Bismark, he used an iron fist in the social conflicts, caused by the birth of the industry, emigration, the birth of the Trade Unions and the Socialist Party, and the beginning of expansion to Africa. ${ }^{3}$ Giovanni Giolitti (1842-1928) was Prime Minister almost without interruption from 1903 to 1914, inheriting a country shaken by social unrest, repressed by the army, and the assassination of king Umberto during Crispi's government. Giolitti, convinced that armed repression was bad for the interests of the northern, progressive, industrial middle class that had given him the power, favored the development of parties and trade unions and widened franchise with the electoral reform of 1913. The contradictions of Giolitti's government, which saved the old transformism, patronage system and corruption, led to the break with the reactionary, right wing agrarians and extreme left wing Socialists. This break laid the basis for the conquest of Libya (1911) and, later, the entering of Italy into the First World War, to which he was opposed. 
small cameos on battles as well as the use of news extrapolated from travel magazines, fictionalized in a dramatic and "extreme" way. Another characteristic is his glorification of human progress, identified with technological innovation bending nature to its will but which contradicts Man's elemental, noble feelings. We must not forget that during this period the second industrial revolution was flourishing in the Kingdom of Italy: one good example is the description of the steel steamboat in The Sea King, where American technology wins not only the Malayan pirates but also and above all the old colonial powers.

Technology however is used by the pirate prince Sandokan and Salgari himself as a tool of vengeance and not as a means of anticolonial struggle in fact Salgari seems to consider liberation struggles as fights against civilization and progress. His faith in technology reveals itself in the meticulous descriptions of tools and machines such as the description of the mining techniques and the problem of firedamp in the Cycle of the Far West, but it manifests itself also in the continuous botanical and zoological digressions which give his novels a vague Darwinian taste. His almost obsessive, exaggerated representation of exotic settings allowed his reader to enjoy a thrilling entertainment while it seemingly conferred a learned "upper class" varnish to the tale, offering the petit bourgeois of King Umberto's "Italietta" education and moral elevation and the writer it should not be forgotten the possibility of stretching out the text.

Among Salgari's sources we can remember the book by Giulio Ferrario on the Old and Modern Costume (Costume antico e moderno, 1817-34), which he ruthlessly "plundered" either for the Cycle of the Jungle or those of the Buccaneers and the West, the History of America (Storia d.America) by Giuseppe Compagnoni, and the Italian editions of the two principal travel magazines of the time, Il giro del mondo and the Giornale illustrato dei viaggi e delle avventure.

Other important sources as they appear in a list handwritten by the author are the Histoire des plantes (1864) and La vie et les moeurs des animaux (1865) by Louis-Guillaume Figuier which appeared in Italy in 1873 and 1880 respectively. Nature, though described with meticulous pedantry, is seen by Salgari as hostile to man's progress, represented by "the prairie raiders" and above all by the British army or the Spaniards. A Darwinist nature blindly hits the heroes and their enemies, often the latter more than the former, thus rescuing the protagonists and the writer from dangerous cul-de-sacs in the plot. This experience of nature as hostile to human progress represented by the "raiders of the prairie", but also by the Indians is indicative of the distance between the urban catholic Salgari and another famous "inventor" of Indians, Fennimore Cooper, who far from having ever set foot in the west however shared the Protestant dream of America as Eden and Rousseau's appeal to the purity of the pristine.

The progress of civilization which is the deus-ex-machina of every cycle is lived however in a pessimistic way: the British conquests of India and Malaya though bringing technological civilization destroy or make useless male virtues such as courage, honor and generosity. Therefore Salgari's heroes are men at a crossroads, divided between two worlds: their culture and feelings belong to tradition. They are gentlefolk, who have fallen upon evil days such as the Black Corsair or Sandokan, the Malayan prince, but they are also "civilized", that is lovers of technology and progress.

Racism and especially miscegenation offer an important starting point to the plots: Anglo-Indian Ada destroys the sect of the Thugs, the failure of the marriage between the Sioux Yalla and Colonel Devandel is the source of the cycle of the West Sandakan's love for an English maiden is the leitmotif of the cycle of the Malayan pirates. The natives either American or Eastern Indians or Africans are characterized by popular racist stereotypes: strong "noble" characters are such because they are half-breed that is they possess a few drops of civilized blood. Miscegenation however brings bereavement and misfortune, feuds and bloody vengeance ending with the death of all, or almost all the characters except the hero. Negative characters are often a racial abomination such as The King of Crabs in The Queen of the Golden Field ${ }^{1}$ who is an African-Chinese mulatto, which is the farthest mixture from a European standpoint. Since the 19th century's idea of race is so important in Salgari's ideology it is obvious that every character is introduced with his/her racial connotations: Poteva avere quattordici anni. La sua taglia era graziosa e di forme superbamente eleganti. Aveva i lineamenti d'una purezza antica, animati dalla scintillante espressione della donna angloindiana. ${ }^{2}$ (She might be fourteen. She was graceful and her figure superbly elegant. Her features had an ancient purity, animated by the glittering expression of the AngloIndian woman) Era una bella figura di giovane, alta, slanciata, flessuosa, dalla pelle delicatissima d'un bianco leggermente roseo, di quel roseo che solo si scorge sulle fanciulle dei paesi settentrionali, e soprattutto in quelle appartenenti alle razzi anglosassoni ed iscotodanesi. ${ }^{3}$ (She was a beautiful young woman, tall, slender and lithe, the color of her very delicate skin was a light pink white, that rosy color you can only see in the maidens of the northern countries and above all in those belonging to the Anglo-Saxon and Scottish- Danish races). (Minnehaha)... Era una bella donna di venticinque o ventisei anni, alta slanciata, coi capelli e gli occhi nerissimi, i lineamenti energici, e la pelle solo leggermente bruna, con delle indefinibili sfumature rossastre. ${ }^{4}$ (Minnehaha was a beautiful woman twenty-five or twentysix years old, tall and slender, with deep black hair and eyes, strong features and the skin was only lightly dark, with indefinable reddish tints).

Si sarebbe detto che (Nuvola Rossa) apparteneva alla razza indiana pura piuttosto che alla meticcia, poiché la sua pelle era oscura con delle sfumature rossastre assai marcate, i suoi capelli erano lunghi, nerissimi e grossolani, il suo naso aquilino, gli zigomi assai sporgenti e gli occhi piuttosto obliqui come quelli della razza mongola ed un po' cisposi $^{5}$ (One might say (Red Cloud) belonged more to the fullblood Indian race than the half-breed one, since his skin was dark, with very marked reddish tints, his hair was long, very black and coarse, his nose aquiline, his cheekbones very protruding and his eyes rather oblique like those of the Mongolian race and a little gummy). The Native American characters, while burdened with every kind of stereotypes, show a dimension of Greek tragedy so Minnehaha the wild Indian woman with her traits of a sadistic virago is reminiscent of the ferocity of Electra, Clytemnestra, Phaedra and Medea. These heroines are justified by the price of blood and revenge in a family saga more appropriate to a Corsican or Calabrian setting than in than of the great prairies.

Racism is fairly distributed in Salgari's books in fact we can say that apart from the stereotypes such as the continuous use of the word "redskins" (from the French, to be honest) and the insulting descriptions of non European rites and characters also the whites are misrepresented above all the British and in the cycle of the privateers the Spaniards. Lord Wilmore may be considered an emblematic character; he is one of the protagonists of the cycle of the West and embodies the stubborn arrogance of the stereotypical spleenful English lord. Captain Macpherson, moreover, in the Mysteries of 
the Black Jungle is willing to torture his Thug prisoners to gain his ends and take his revenge. The Americans on the other hand even if Salgari describes them more favorably (in The Captain Woman of the Yucatan, The Sea King and the Cycle of the West) cannot escape his mockery, in fact "in that occasion they demonstrated all their legendary American brutality".

The reason why Salgari is acrimonious about the British is easy to understand if we remember the period when his novels are published. Between 1880 and 1911 the Kingdom of Italy's policy was more and more oriented towards achieving "a place in the sun" that is a colonial outlet allowing the solution of internal social and economic conflicts. This imperialist policy, similar to that of Germany and the United States, shows the alliances born during the Risorgimento ${ }^{4}$ reversed: England and France are no more the allied powers which, with their cannons permitted the creation of the Italian nation-state, but the main obstacles to its colonial expansion. These are the years of the tragic expeditions to Ethiopia ${ }^{5}$ and we can hear the echo of the battle of Adua in Salgari's Battle of the Little Big Horn. The Libyan war broke out in 1911, when he committed suicide, though there is apparently no connection between the two events. We can understand this way his hostile stance against Britain's imperial power and somewhat sympathetic yet ambiguous attitude to young nations or invaded peoples, although he never forgets an appeal to the values of civilizing conquest.

What a difference between Salgari's and Kipling's “white man's burden"! But we must not confuse Salgari's anti-colonial arguments, which are particularly anti-British with some emotional attachment with the cause of the losers of whom Salgari does not care about. In fact, he shows neither the philological research of colonial officials like Kipling, neither the hard criticism of imperialism of Conrad's Heart of Darkness. Salgari's heroes are quite "savage", prey of elemental feelings and ready to strip away their thin film of civilization: they tend in fact towards the Nietzschean superman who, however, has more a taste of Carducci's than D'Annunzio's or Nietzsche's. He does not feel any pity for the losers, especially if they fight their fate waging war: in this case, they are only "savages", urged on by their wild instincts and not by reason:

L'indiano non volle piegarsi alla dura legge del lavoro, che è la legge dell'umanità, non volle scavare il suolo e fecondarlo con i suoi sudori. (...) Giunse l'uomo bianco che portò su questo vasto continente una energia e un ardore indomabili, e quel giorno segnò la caduta della razza rossa. (...) L'antico guerriero si è trasformato in un indegno aguzzino. ${ }^{1}$ (The Indian did not want to bow to the hard law of work, which is the law of mankind, he did not want to dig the soil and nurture it with his sweat. (...) Then the white man came, bringing

${ }^{4}$ During the Risorgimento, from the Vienna Congress (1815) to the conquest of Rome (1870), most of Italy became united after the First War of Independence (1848-49), the Second War of Independence (1859), the Expedition of the Thousand (1860), the Third War of Independence (1866) and the conquest of Rome, with the subsequent end of the Pope's temporal power.

${ }^{5}$ The imperialist expansion of Italy occurred in a scenario, in Eastern Africa, where France (French Eritrea and Djibouti) and Britain (protectorate on Egypt and Sudan and the Kenyan colony) were also operating. The Italian adventure in Eastern Africa began with Cardinal Massaja purchasing Assab Bay on behalf of Rubattino Co.; in 1887 Prime Minister Crispi bought the Bay and sent the Italian army to conquest Asmara, capital of Eritrea; although stopped by the Eritreans at Dogali, he annexed the territory after the death of the Negus. The new Negus destroyed Crispi's plans for an African empire; a very fierce war broke out and the Italian army was defeated at Amba Alagi and especially at Adua (1896), where 6,6000 Italians died. The defeat closed a period of history. untamable energy and ardor to this vast continent and that day the red race was doomed. (...) The ancient warrior became an abominable torturer.)

Sometimes they are fanatic barbarian nationalists who will be exterminated by the bearers of civilization:

"Disprezza gli incensi e le preci, non vuole che vittime. Quella donna (Kalì) rappresenta la libertà indiana e la distruzione dei nostri oppressori dalla pelle bianca". "Ti fanno orrore i thugs? Forse perché strangolano? Gli europei ci schiacciano col ferro dei loro cannoni, noi li schiacciamo col laccio, l'arma della nostra possente dea": ${ }^{2}$ "'She despises incense and prayer, she wants only victims. That woman (goddess Kali) represents Hindu freedom and the destruction of our white skinned oppressors." (...). "Do you feel horror for the Thugs? May be because they strangle? Europeans crush us with the steel of their cannons; we crush them with the noose, our powerful goddess's weapon".)

In Salgari's stories the natives act like Nature's forces or help underline the white heroes" human qualities":

“... bestie umane, diavoli Apache, peggiori delle tigri, ${ }^{6}$ sempre feroci, anche contro la gente della loro razza" [“... human wild beasts, Apache devils, worse than tigers, always fierce, even against people of their race". The wild nature of the natives is further stressed by the "splatter effect", which somewhat characterized much of Salgari"s prose: "L'ascia di Minnehaha si era staccata allargando la ferita, e dallo squarcio uscivano fiotti di sangue e brani di cervello". (Minnehaha's axe came off widening the wound, and spurts of blood and fragments of brain came out of the gash.) "Sitting Bull, armato di un tomahawk, scese solo nel cañon, s'avanzò attraverso quella distesa di cadaveri, raggiunse il generale che era caduto in mezzo ai suoi ultimi ufficiali, gli spaccò il petto e levatone il cuore che era ancora caldo lo divorò coll'avidità dell'antropofago, fra le urla entusiastiche dei suoi quattromila guerrieri!, ${ }^{6}, 4$ (Sitting Bull, armed with a tomahawk, went down to the canyon alone, advanced through the expanse of corpses, reached the general who had fallen among his last officers, smashed his chest and, still warm, he pulled the heart out, devouring it with a cannibal's greed, amidst the enthusiastic shouts of his four thousand warriors!).

Also his "patchwork" descriptions of the natives are racist, where the Indians are piled up regardless of where they actually lived, almost all Indians wear Plains style war bonnets ringed with gold (!), live in wigwams and torture their prisoners at totem poles, practice the Sun dance and are governed by sachems. Most terms are, of course, careless: Spanish and English words are mixed up with indigenous ones written with a mangled spelling in order to create exotic sounds. These foreign words, often learnt by heart and therefore, inopportunely and differently spelled in the same story contribute either creating an alien wild atmosphere because savage peoples have uneducated languages or giving the tale a varnish of scientific truth a sensation which is enriched also by numerous historical background digressions though often indulging to the Grand Guignol.

${ }^{6}$ Wishing 'a place in the sun' and always excluded from the international conferences where the great powers divided the world among themselves, Italy, encouraged by its participation in the international expeditions against the Chinese Boxers, invaded Libya. The war was long and very brutal, with air bombardments and the use of gases.

${ }^{7}$ The original edition has the note 'historical', but Salgari copied this detail from uncheckable sources such as Boussenard's novel, Adventures of a Paris Scamp in Buffalo Country. 
Warrior women reinforce Indian savagery once more their fierce cruelty compares well with fragile white gentlewomen who though intrepid are on the whole mawkish and needing the hero's help. Native women on the contrary often win men and animals on points. "Anche se tra essi vi fossero delle donne?" "Esse prima di tutti". "Perché .Quale colpa hanno?" "Sono più terribili degli uomini. Rappresentano la dea Kali": ' "Even if among them there are some women?" "Them more than others" "Why? What's their sin?" "They are more terrible than men. They represent goddess Kali.").

La squaw, vedendo i cacciatori puntare i fucili, aveva subito gridato: "Non fate fuoco visi pallidi!..." Poi un sibili modulato uscì dalle sua labbra, ed orsi e giaguari, coguari e perfino lupi si arrestarono di colpo. ${ }^{6}$ (The squaw, seeing the hunters aiming their rifles at her, had cried at once: "Don't fire, palefaces!..." Then a modulated whistle came out of her lips, and bears, jaguars, cougars and even wolves stopped abruptly). “... e per salvare la capigliatura aveva dovuto sposare Yalla, una bellissima indiana, figlia di un famoso capo. Voi sapete la repulsione istintiva che proviamo tutti noi uomini bianchi per la razza rossa.. ("“...and to save his scalp he had to marry Yalla, a very beautiful Indian woman, daughter of a famous chief. You know the instinctive repulsion all we white men feel for the red race").

"(Minnehaha) ha superato sua madre per valore e ferocia, per audacia e soprattutto per crudeltà. Sette volontari che erano sfuggiti al massacro della gola del Funerale, dopo quindici anni sono stati trovati da Minnehaha e scotennati con le proprie mani, dopo aver fatto subire a quei disgraziati le torture del palo": ("Minnehaha has surpassed her mother for bravery and savagery, audacity and above all cruelty. Seven volunteers who had escaped the massacre at the Funeral gorge, after fifteen years were found by Minnehaha who scalped them with her own hands, after she had tortured those poor wretches at the stake").

"Disgraziatamente ella era rossa e io bianco e l'odio istintivo non doveva tardare a scoppiare tra noi: d'altronde non avevo mai sognato di sposare una donna di colore diverso, feroce come tutti quelli della sua razza, che combatteva sempre in prima fila e che si mostrava, verso i prigionieri, di una crudeltà inaudita".5 ("Unfortunately she was red and I was white and the instinctive hatred did not take long to break out between us: on the other hand I had never dreamed of marrying a woman of a different color, as fierce as all of her race, who always fought in the front line and showed an unheard-of cruelty to the prisoners"). It is possible that Salgari influenced by the news in the illustrated magazines had been impressed by the deeds of the suffragettes of his period (the English ones were particularly militant) and in some way depicted these modern 'warrior women' in the fierce, strong heroines of his novels.

This ambiguous contradictory writer however paid homage to those characters who defeated knew how to die with honor and wild passion: Salgari in fact especially admired the supermen the Wagnerian heroes of a colonial Ragnarock. In some ways Salgari was faithful to the popular feelings of the Italian petit bourgeois, especially those low rank civil servants of whom there were many within the
Italian bureaucracy afraid of any change or novelty which might jeopardize their precarious well-being. Yet those Catholic Philistines childishly dreamed of faraway lands, heroic adventures, powerful feelings and exotic encounters with (sexually) unrestrained savage women and strange peoples that confirmed by means of their wildness the civilizing western values.

This is the reason why Salgari's books were absolute best-sellers for a very long time even if they made rich not their author but the publishers. The stereotyped "Other" so excessive and alien of his stories formed the Italians' collective unconscious together with the famous colored plates of the "Domenica del Corriere", laying out the premises for the Thirties' and Forties' Adventure cartoons the great success of Cinecittà, (the studios near Rome) and in spite of Fascism Hollywood movies. We can say that Salgari and particularly his Cycle of the West had the same importance in Italy as Carl May in Germany and Zane Grey in the USA: after all every lover of Indians has romantically hoped to meet one of those wild, fascinating, absolutely exaggerated natives at his first encounter. ${ }^{8-11}$

\section{Acknowledgements}

None.

\section{Conflict of interest}

Author declares that there is no conflict of interest.

\section{References}

1. Emilio S. La sovrana del Campo d'oro. Fabbri Editori, Milano, Europe; 1968.

2. Emilio S. I misteri della jungla nera. Ugo Mursia Editore, Milano, Europe; 2000. p. 41.

3. Emilio S. Il corsaro nero. Ugo Mursia Editore, Milano, Europe; 1998.

4. Emilio S. La scotennatrice. Ugo Mursia Editore, Milano, Europe; 1973. p. 248.

5. Emilio S. Sulle frontiere del Far-West. Ugo Mursia Editore, Milano, Europe; 1993. p. 44.

6. Emilio S. Le due tigri. Ugo Mursia Editore, Milano, Europe; 1999. p. 272.

7. Emilio S. Le Selve Ardenti. Ugo Mursia Editore, Milano, Europe; 1992. p. 208.

8. Emilio S. I pirati della Malesia. Ugo Mursia Editore, Milano, Europe; 1992.

9. Emilio S. Il re del mare. Ugo Mursia Editore, Milano, Europe; 1998. p. 312 .

10. Emilio S. La regina dei Caraibi. Ugo Mursia Editore, Milano, Europe; 1993. p. 320

11. Emilio S. Jolanda la figlia del Corsaro nero. Ugo Mursia Editore, Milano, Europe; 1990. p. 280 